\title{
冷却空洞が発生した密封管の急開封時の水繁*
}

\author{
中 川 順 達*1, 竹 中 俊 夫*2
}

\section{Waterhammer in Quick Opening a Closed Pipe with a Cooling Cavity}

\author{
Masamichi NAKAGAWA and Toshio TAKENAKA
}

\begin{abstract}
Since the closed pipe under generation of the cooling cavity holds the low pressure near the saturation vapor pressure, quickly opening of the valve at an end of the pipe in that condition, the cavity is collapsed by the impressed atmospheric pressure, and an intense waterhammer occurs. The above phenomenon is modeled by the rigid column theory. The theoretical expression is derived to give the maximum pressure rise using the volumetric fraction of the cavity, the impressed pressure difference, the density and the sonic velocity of the liquid in the pipe. The estimated curve is compared with the experimental data. A weak buffer effect of the air in the cavity is shown quantitatively by the experiment. Because of the air containment, the cavity does not completely disappear and some bubbles of air remain after the collapse.
\end{abstract}

Key Words: Fluid Transients, Waterhammer, Cavity Collapse, Rigid Column Theory, Pressure Surge, Maximum Pressure Rise, Potential Magnification

\section{1. 緒}

\section{함}

周囲の環境よりも温度が高い液体を流す管路では， 液体が管路内に密封される形で流れを止められると， 冷却に伴って液体が収縮するため, 管路内は吸引減圧 状態になり，空洞が発生することがある(1)(2).

こうした冷却空洞が発生した密封管では，管内の圧 力が飽和蒸気圧近くまで低下しているため，そのまま の状態で一端の弁を急に開くと，吸引減圧状態の空洞 がラインの圧力ないし大気圧によって急激に押しつぶ されるため，思わぬ水撃が発生し，危険である(1)。

著者らのこれまでの実験では，その最大圧力上昇が, 印加圧力差の 10 倍以上という異常な高さに達してい る.したがって、こうした現象は，予期せぬプラント事 故の原因としても，将来的に予想される大地震時の二 次災害の防止対策としても，解明しておく必要があ る.

そこで本稿では，こうした水撃現象を剛体理論でモ デル化し，理想化したモデル実験を行って，その発生

* 原稿受付 平成 2 年 9 月 4 日.

*1 正員, 東京工業大学工学部（\$152 東京都目黑区大岡山 2-12 -1).

*2 正員, 武藏工業大学工学部（１58 東京都世思谷区玉堤 1-28 $-1)$.
を確認し，最大圧力上昇の定量的検討を行うとともに， 現象の本質に即した，その新しい評価法を提示する。

\section{敦 号}

$a:$ 管内の音速 $\mathrm{m} / \mathrm{s}$

$C_{1}:$ 管の拘束係数 ${ }^{(3)}$

$D:$ 管の内径 $\mathrm{m}$

$e:$ 管の肉厚 $\mathrm{m}$

$E:$ 管材料の綐弾性係数 $\mathrm{Pa}$

$K$ : 液体の体積弾性係数 $\mathrm{Pa}$

$L$ :管の長さ $\mathrm{m}$

$l:$ 空洞の等価長さ $\mathrm{m}$

$P$ :压力 $\mathrm{Pa}$

$w:$ 液柱の速度 $\mathrm{m} / \mathrm{s}$

$\eta$ :ポテンシャル倍率 $[2 \cdot 4$ 節, 式 ( 9 )参照

$\lambda:$ 管摩擦係数

$\rho:$ 液体の密度 $\mathrm{kg} / \mathrm{m}^{3}$

$\phi:$ 空洞率 $(=l / L) \%$

添字

atm：大気

imp : 印加

$0 ：$ 初期

crsl : 液柱の閉鎖端鏡板への最初の衝突 


\section{2. 水早圧力の解析}

\section{$2 \cdot 1$ 現象の理解と解析の方坽 本稿の過渡現象}

は, 压力印加による空洞境縮現象 (Cavity Collapse) である．すなわち，冷却空洞が発生した状態の管内の 初期流速は当然雺であり，そこに弁の急開放などによ って, 冷却空洞現象のために大きく隇圧した管内圧力 より高い圧力が管外から印加されると, 過渡現象が発 生し，空洞がつぶされる現象である。

したがって，通常の水整や従来の液柱分離・再結合 では，非雺の流速を初期条件として，弁閉鎖によって 発生する水盤圧力か問題になるのに対して，本稿の現 象では，冷却空洞現象によって大きく減圧した管内圧 力と, 管外圧力との圧力差を初期条件として, 弁開放 によって発生する水撃圧力が問題となる点が，本質的 に重要である。

そこで本稿では，こうした点を踏まえて，印加圧力 差に対して水撃圧力を整理し，その比を用いて異常高 圧が評価できるようにすることを，最終目標とする。

$2 \cdot 2$ モデリング 最高水撃圧力は, 初期圧力と 最大圧力上昇の和

$$
P_{\max }=P_{0}+\Delta P_{\max }
$$

で表せる，また一般に，流体過渡現象における圧力上 昇と流速変化の夙係は，ジュコフスキーの式

$$
\Delta P=\rho a \Delta w
$$

で表せるから，結局次式が成り立つ。

$$
\left\{\begin{array}{l}
\Delta P_{\max }=\rho a \Delta w_{\max } \\
P_{\max }=P_{0}+\rho a \Delta w_{\max }
\end{array}\right.
$$

本現象においても，他の多くの流体過渡現象と同様 に, 最高水慗圧力を示すのは, 圧力変功の第 1 ピーク であるから，最大流速変化 $\Delta w_{\max }$ は，液柱が閉鎖端に 最初に衡突するとき生ずる.このときの速度を $w_{\mathrm{crsl}}$ と すると、初期流速零だから，以下の式が得られる。

$$
\begin{aligned}
& \Delta w_{\max }=\left|0-w_{\mathrm{crsl}}\right|=w_{\mathrm{crs} 1} \\
& \therefore\left\{\begin{array}{l}
\Delta P_{\max }=\rho a w_{\mathrm{crsl}} \cdots \cdots \\
P_{\max }=P_{0}+\rho a w_{\mathrm{crs} 1}
\end{array}\right.
\end{aligned}
$$

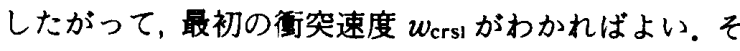
こで, 図1に示すように剛体理論でモデル化する.

\section{$2 \cdot 3$ 䟾初の街突速度 液柱の運動方程式は次式}

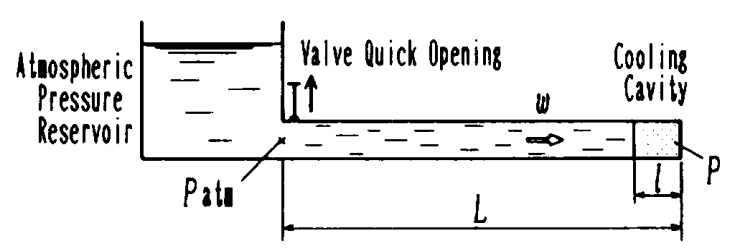

図 1 冷却空洞㙽䑿時の㣚体理論によるモデル化
となる，管の傾斜度の影非は，微小なので無視した。

$$
\begin{array}{r}
\rho(L-l) \frac{d w}{d t}=\left(P_{\mathrm{atm}}-P\right) \\
-\frac{\lambda}{2} \frac{(L-l)}{D} \rho|w| w \cdots
\end{array}
$$

前稿(2)により, 空洞率 $\phi=l / L \fallingdotseq 0.02$ であるから, $l(\ll$ $L)$ を無視して整理すると，次式を得る。

$$
\frac{d w}{d t}=\frac{P_{\mathrm{atm}}-P}{\rho L}-\frac{\lambda}{2 D}|w| w
$$

過渡現象開始後, 最初の衙突までの正流 $(w \geqq 0)$ 条件 の下で式(4)を解くと, 次式を得る.

$$
w_{\mathrm{crsl}}=\sqrt{\frac{2 D}{\lambda} \frac{\left(P_{\mathrm{atm}}-P\right)}{\rho L}\left(1-e^{-\frac{\lambda}{D} l}\right)}
$$

これを式(1)，（2）に代入すれば, 各圧力值が求まる. 一般に $\lambda=0.02, \phi=l / L=0.02$ 程度であるから， $x=$

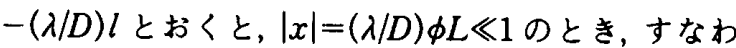
ち $L / D<250$ 程度のとき, $e^{x}=1+x$ という近似が成

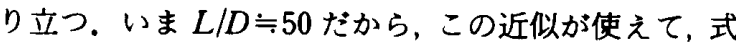
( 5 )は以下の形にまで整理できる.

$$
w_{\mathrm{crsl}}=\sqrt{\frac{2\left(P_{\mathrm{atm}}-P\right)}{\rho} \phi}
$$

$2 \cdot 4$ 水察压力 これを式(1)，(2)に代入すれ ば，水慗圧力は，以下の简単な形の式で表せる。

$$
\begin{aligned}
& \Delta P_{\max }=a \sqrt{2 \rho\left(P_{\mathrm{atm}}-\bar{P}\right) \phi} \\
& P_{\max }=P_{0}+a \sqrt{2 \rho\left(P_{\mathrm{atm}}-P\right) \phi}
\end{aligned}
$$

いま扱っているような圧力印加型の流体過渡現象に おいては，流速条件が表立って与えられないため，ジ ュコフスキーの式を直接使うことはできない。そこで, ジュコフスキーの式に基づいて導いたこの式（7)が, ジュコフスキーの式に代わって，その最大圧力上昇を

見糟もる重要な役割を担うことになる。

ここで, 印加圧力差 $\Delta P_{\mathrm{Imp}}$ を基準にして, 最大圧力 上昇を無次元化したポテンシャル倍率

$$
\eta=\frac{\Delta P_{\max }}{\Delta P_{\mathrm{imp}}}=\frac{\Delta P_{\max }}{P_{\mathrm{atm}}-P}
$$

を定義し，これに式(7)を代入すると，次式が得られ る。

$$
\eta=a \sqrt{\frac{2 \rho \phi}{\left(P_{\mathrm{atm}}-P\right)}}
$$

これは, 印加压力差を入力とし，最大圧力上昇を出力 とする，本稿の水媻を特徴付ける伝達関数でもある。

\section{3. 实験装而と实験方法}

$3 \cdot 1$ 实験装圌図 2 に実験装置の概略を示す.寒 験は傾斜度 $1 / 50$ に設定した架台の上で, 断熱用発泡 スチロール片により無拘束支持した密封管で行った。

密封管は, 内径 $20 \mathrm{~mm}$, 肉厚 $5 \mathrm{~mm}$, 長さ $1 \mathrm{~m}$ の透 明アクリル製で，一端がボール弁，他端が盲端である。 
ボール弁は, 貫通口の内径が管の内径と同じ $20 \mathrm{~mm}$ のものを使用し，全開時には弁による損失が問題にな らなくなるように工夫した。盲端の鏡板には，外径 0.5 $\mathrm{mm}$, 長さ $500 \mathrm{~mm}$ の K 型シース熱電対と，温度補供 型圧力変換器が取り付けてある. 両センサの出力は, 室温测定用の熱電対のそれと共に, ペンレコーダに記 録する。

$3 \cdot 2$ 実験方法 冷却空洞を発生させ, 熱平衡に 達したところで空洞率を測定 (前稿(2)参照) した後, ボ 一ル弁を急開放し，このときの閉鎖端における圧力変 動を，電磁オシロに記録する。

\section{4. 結果の検村と考察}

4.1 圧力变動 本稿の一連の実験では, 初期条 件の圧力 $5 \pm 2 \mathrm{kPa}$, 空洞率 $2.2 \pm 0.1 \%$, 空気㴤度 (空 気分圧比 $\left.P_{\mathrm{air}} / P\right) 47 \pm 24 \%$ ，最終条件は大気圧（101.3 $\mathrm{kPa})$ ，空気漫度 $97.5 \%$ であった。印加圧力差 $96 \pm 2$ $\mathrm{kPa}$ に対して, 第 1 ピーク圧力は $912 \pm 77 \mathrm{kPa}$ に達 している，図3に電磁オシロの記録チャートの一例を 示す. 圧力変動の波形全体の特徵は，第 1 ピークで最 大となり，第 $1 \sim 2$ ピーク間周期にして $23 \pm 3 \mathrm{~ms}$ $(44 \pm 6 \mathrm{~Hz})$ で 0.2 0.3 $\mathrm{s}$ 程度て隇衰する。

䉆くべきことに，最高水準圧力は $992 \mathrm{kPa}(9.8 \mathrm{kgf} /$ $\mathrm{cm}^{2}$ )に達している。最大圧力上昇 $989 \mathrm{kPa}$ は, 印加圧. 力差 $(96 \pm 2 \mathrm{kPa})$ の実に 10.1 倍である.

観察によれば，空洞は完全に消隇せず，壊縮後も気 泡がいくつか残る。このときは分圧比で $97.5 \%$ が空気

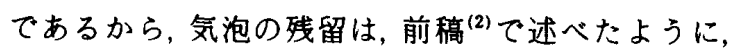
空洞内へ空気が放散していたことを旁付けている。

4.2 最大圧力上开図 4 に空洞率との関係を示 す.プロット群を拡大表示したため，多少ばらついて 見えるが，両者の間に正の相関があることがわかる.

このことは，2章の解析で真いた式 ( 7 )と合致する。

そこで, 実験結果と解析結果を直接比較してみる。 図 4 中の実線は, 以下の実験値を用いて求めた式 ( 7$)$ の計算値である，なお，弁が開き始めてから完全に開 き終わるまでの間 $(0.05 \mathrm{~s}$ 程度)に第 1 ピークが生じて しまう (半周期の $0.012 \mathrm{~s}$ 程度) ことを考虑して, 実効 值として根号内を 0.4 倍にして計算した。

$$
\begin{aligned}
& D=0.02 \mathrm{~m}, \lambda=0.02 \text { (一定), } L=1.222 \mathrm{~m}, \\
& P_{\mathrm{atm}}-P=96.2 \mathrm{kPa}, \\
& \rho=998 \mathrm{~kg} / \mathrm{m}^{3}, l=0.027 \mathrm{~m} \quad(\phi=0.022 \text { に相当) }
\end{aligned}
$$

また，管内の音速は，次式によって種々の場合につい て試算し, $a=700 \mathrm{~m} / \mathrm{s}\left(K=2.22 \times 10^{9} \mathrm{~Pa}, E=2.8 \times\right.$ $10^{9} \mathrm{~Pa}, e=0.005 \mathrm{~m}, C_{1}=1.116$ に相当）とした.

$$
a=\sqrt{\frac{K}{\rho}} \sqrt{\left(1+\frac{K}{E} \frac{D}{e} C_{1}\right)^{-1}}
$$

計算值の実線の傾きは，実験值の相関性と一致して いるといえる.したがって，本稿の水撃の本質は，2章

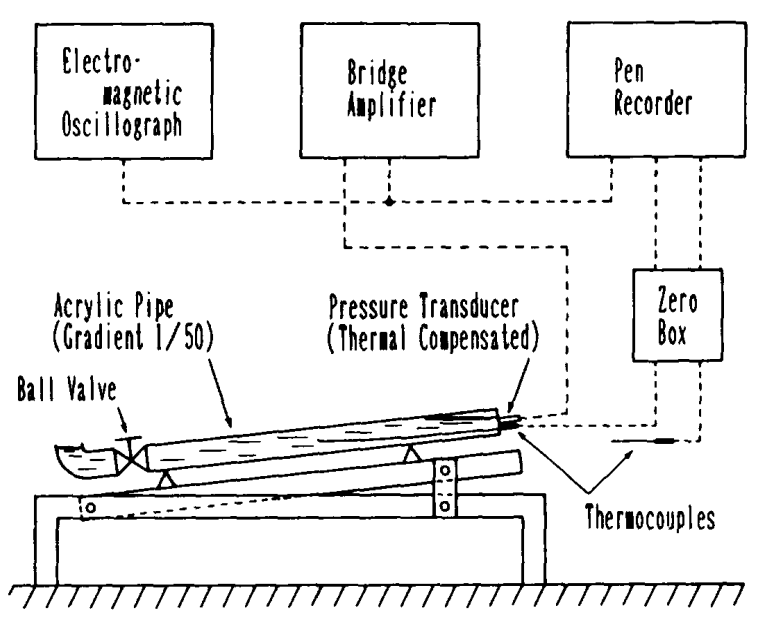

図 2 実験装置の概略

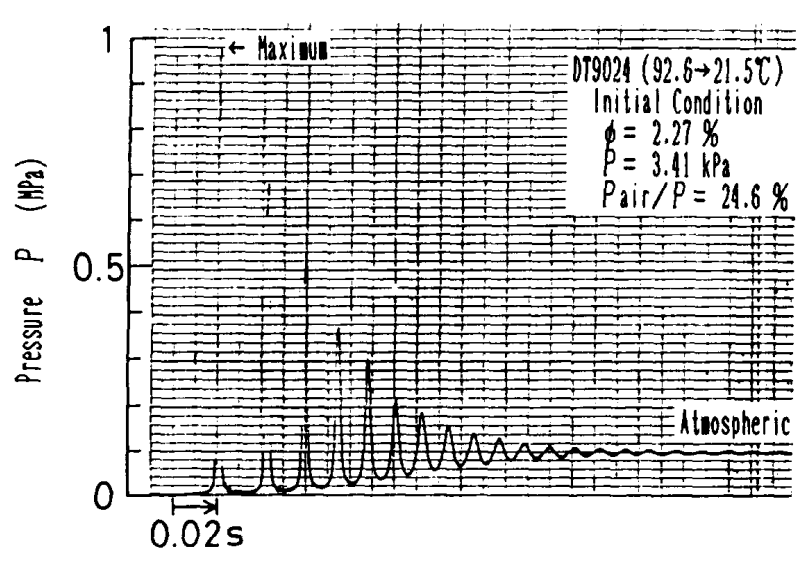

図 3 圧力変動の記録波形の一例

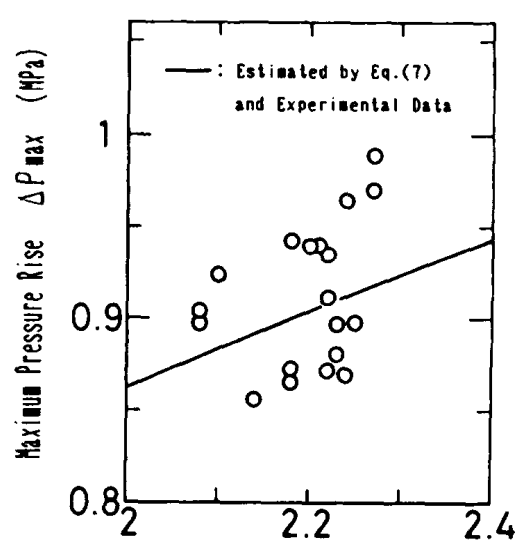

Cavity Fraction $(\%)$

図4最大圧力上昇と空洞率の関係 


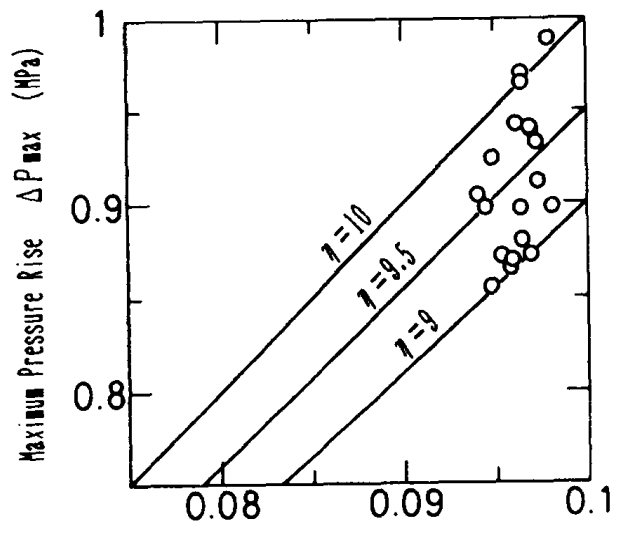

Inpression Potential Patr-P ( $\mathbb{P P a})$

図 5 最大压力上昇と印加圧力差の関係

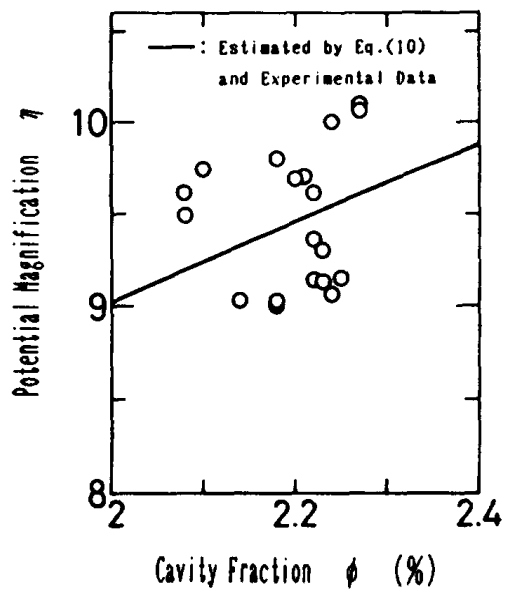

図 6 ポテンシャル倍率と空洞率の関保

の解析のように理解することができる.

$4 \cdot 3$ ポテンシャル倍案 図 5 に最大圧力上昇と 印加圧力差の関係を示す。両座標軸の目盛の比からわ かるとおり, 最大圧力上舁は, 印加圧力差の 10 倍程度 の大きさにも達している．図 5 中に $2 \cdot 4$ 節で定義した

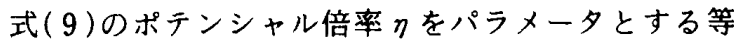
倍率線を描き込むと，本実験の籍囲では， $\eta=9.5 \pm 0.6$ であることがわかる。さらに，管路が長く弁が開き終 わる夕イミングが問題にならない場合， 0.4 倍の補正 を行わずに，式(10)に上揭の実験値を代入すると，本 実験值の 1.5 倍に当たる上限值 $\eta=15.0$ が得られる.

そこで, 本稿の水擊に備えて対策を立てる際には， 先に適切な $\eta$ を与えて, 式 (9) から逆算して最大圧力 上昇を見樌もる方法も，実用上有用であると考えられ る.

図 6 にポテンシャル倍率と空洞率の関係を示す．図 4 と同様, 多少ばらついて見えるが，やはり両者の間

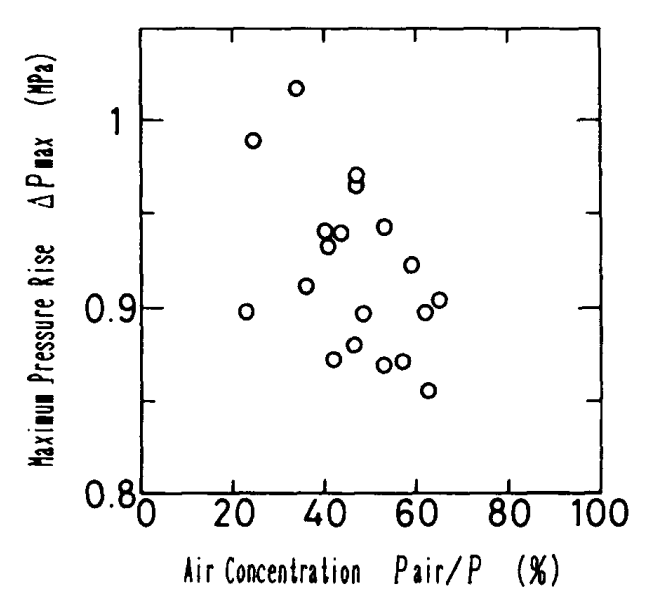

図 7 最大圧力上昇と空気漕度の関係

に正の相関がある。図6中の実線は，上揭の実験値を 用いて求めた式(10)の計算值である，その傾きは，実 験值の相関性と一致しており，圧力印加型の水撃に対 する，2 章の解析の妥当性が再度確かめられた。

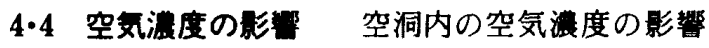
を調べるため, 図 7 に最大圧力上昇と空気分圧比の関 係を示す．図 7 から両者の間に負の相関があることが わかる，空気濃度が $50 \%$ 增すと，最大圧力上昇は 0.2 $\mathrm{MPa}$ 低下することが読み取れるから，空洞内の空気 には，本実験の筑囲 (20〜70\%)では，最大圧力上昇に 対して， $-4 \mathrm{kPa} / \%$ 程度の弱い緩衝効果があること がわかる，この理由は，液柱が空洞を押し縮めるにつ れて，空洞内の空気が䈨縮されてばねのように働き， 衝突間際の液柱の運動を押しとどめようとすると考え られるから，したがって，空気湌度 (空気分圧)が高い ほど, 最大圧力上昇が抑えられるものと考えられる。

\section{5. 結}

蹁

冷却空洞が発生した密封管では，そのままの状態で 一端の弁を急に開くと，空洞が管外との圧力差によっ て急激につぶされる, 圧力印加型の激しい水撃が発生 する。本稿では，これを㓮体理論を用いてモデル化し， その最大圧力上昇を与える理論式を導き，理想化した モデル実験の結果と比較して，その妥当性を確認し た.

\section{文献}

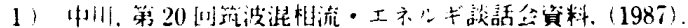

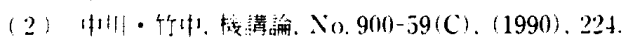

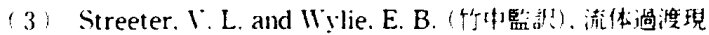

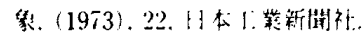

